\title{
Ossicular status in patients operated for chronic suppurative otitis media
}

\author{
Sharma $\mathbf{M}^{1}$, Shetty D.P \\ ${ }^{1}$ Dr Monika Sharma, Assistant Professor, Department of ENT, Head and Neck Surgery, Sree Narayana Institute of \\ Medical Sciences, Ernakulam, Kerala, ${ }^{2}$ Dr Devi Prasad Shetty, Professor, Department of ENT, Head and Neck Surgery, \\ Kanachur Institute of Medical Sciences, Mangalore, Karnataka, India.
}

Address for Correspondence:Dr Monika Sharma, Assistant Professor, Department of ENT, Head and Neck Surgery, Sree Narayana Institute of Medical Sciences, Ernakulam, Kerala. Email: dr_msharma@rediffmail.com

\begin{abstract}
Introduction: Chronic suppurative otitis media (CSOM) is a chronic inflammation of the middle ear and mastoid cavity, which presents with recurrent ear discharge through a tympanic perforation. The WHO has classified India as a country with highest prevalence $(>4 \%$ ) requiring urgent attention to deal with a massive public health problem. CSOM is often associated with a bone eroding process which occurs due to the presence of cholesteotoma, granulation tissue or both. Methods: This study was conducted in a department of E.N.T, Yenepoya Medical College Hospital, Deralakatte, Mangalore for a period of 2 years. This study was conducted to evaluate the ossicular involvement in chronic suppurative otitis media (CSOM). A retrospective-prospective study was conducted over a 2-year period on 86 patients who underwent surgery for the disease. Demography, ossicular status and hearing loss were studied and analyzed using SPSS programme. Results: The study revealed Tubotympanic disease was the more common type of disease. Ossicular necrosis was present in $35 \%$ of population. The most common ossicles involved were the whole of incus, followed by lenticular process and long process of incus. There was a higher incidence of ossicular disruption in atticoantral disease than in tubotympanic disease.
\end{abstract}

Key words: CSOM, Ossicular necrosis, Atticoantral disease, Tubotympanic disease.

\section{Introduction}

Chronic suppurative otitis media (CSOM) is a chronic inflammation of the middle ear and mastoid cavity, which presents with recurrent ear discharge through a tympanic perforation. The WHO has classified India as a highest prevalence country requiring urgent intervention [1].

CSOM is often associated with a bone eroding process which occurs due to the presence of cholesteotoma, granulation tissue or both. The activity if unchecked will eventually lead to invasion and destruction of inner ear, dural plate, sinus plate, ossicles and facial canal and extend beyond the confines of temporal bone resulting in high morbidity and at times even mortality. Surgery is frequently done in these patients for eradication of the

Manuscript received 24 $4^{\text {th }}$ August 2016

Reviewed: $7^{\text {th }}$ September 2016

Author Corrected: $17^{\text {th }}$ September 2016

Accepted for Publication 30 $30^{\text {th }}$ September 2016 disease process. Good postoperative functional result demands proper preoperative and peroperative assessment of pathology, as well as their correlation with the extent of damage to the ossicular chain. This study was undertaken to assess and correlate types of pathology with the extent of ossicular damage in such patients.

This study revealed the prevalence of CSOM of tubotympanic is more common than atticoantral disease. This study also helped compare the degree of ossicular involvement in tubotympanic and atticoantral disease.

\section{Materials and Methods}

This study was conducted in the Department of ENT, Head and Neck Surgery, Yenepoya Medical College Hospital, Mangalore for a period of 2 years. The study consisted of 86 patients with chronic suppurative otitis 
media. All these patients underwent tympanoplasty with or without mastoidectomy.

The patients were divided into two groups; Group 1, those with tubotympanic disease and Group 2, those with atticoantral disease.

All patients were assessed for the presenting symptoms, duration of complaints, last episode of ear discharge, otoscopic findings, type and degree of hearing loss.

Mastoid pneumatisation and anatomy were assessed with X-ray mastoid. (lateral and oblique view).

Intraoperatively the ossicular chain status, condition of the middle ear mucosa, other pathology like granulation, extent of cholesteatoma were noted and recorded.

Inclusion Criteria- All cases of chronic suppurative otitis media undergoing surgery.

\section{Exclusion Criteria}

1. Cases of revision surgery for chronic suppurative otitis media.

2. Patients with secretory otitis media.

3. Children below 10 years.

\section{Observation and Results}

A total of 86 patients were studied. The results are as follows.

Age Incidence: In our study, the maximum number of patients were in the age group 21-30 years, followed by 11-20 years, which together accounted for $66.28 \%$.

Table-1: Type of disease

\begin{tabular}{|c|c|c|}
\hline Type of Disease & No. of patients & Percentage \\
\hline Atticoantral disease & 18 & 21 \\
\hline Tubotympanic disease & 68 & 79 \\
\hline
\end{tabular}

Table 1 Type of Disease- $69.77 \%$ of the patients had central perforation. Total perforation had the least incidence in our study at $2.333 \%$.

Table-2: Ossicular necrosis.

\begin{tabular}{|c|c|c|}
\hline & No. of patients & Percentage \\
\hline Present & 30 & 35 \\
\hline Absent & 56 & 65 \\
\hline
\end{tabular}




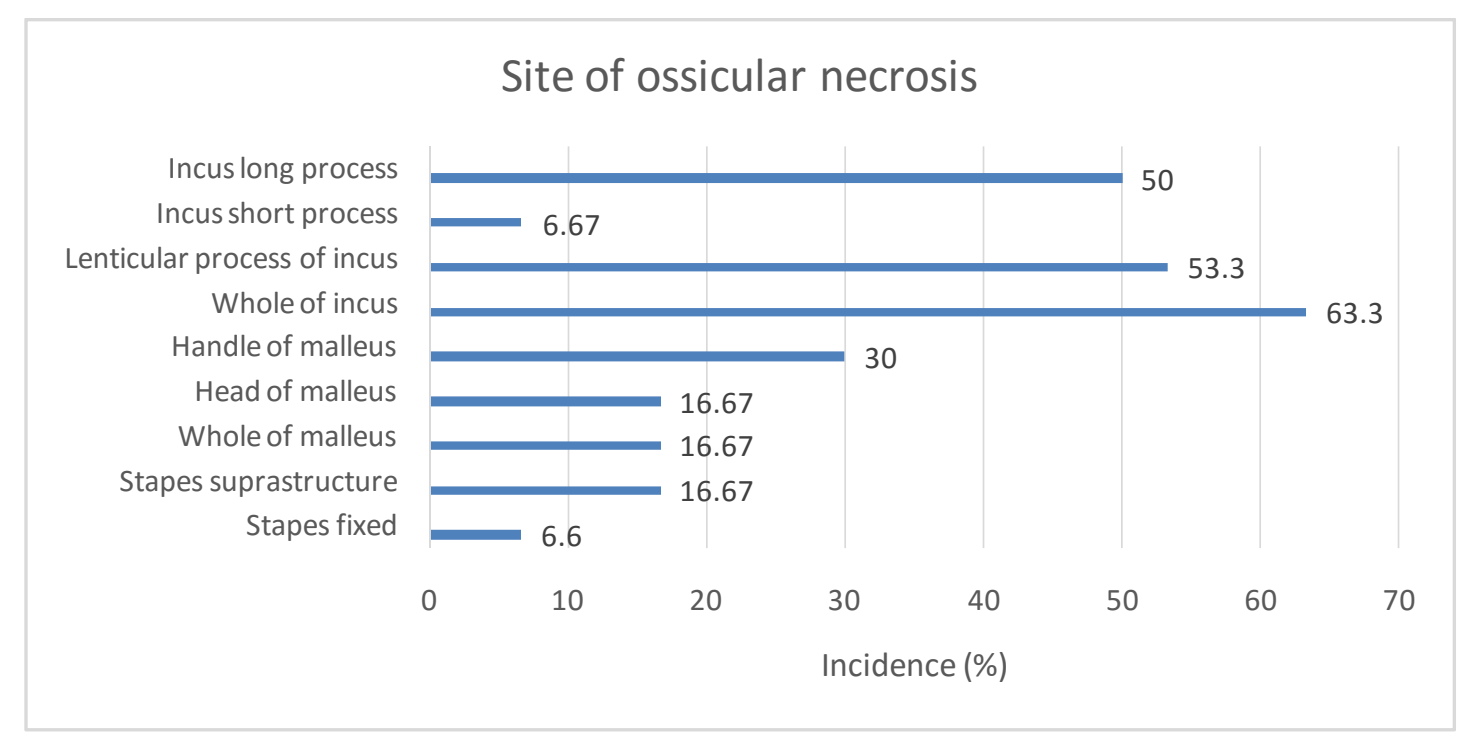

Fig 1: Site of ossicular necrosis

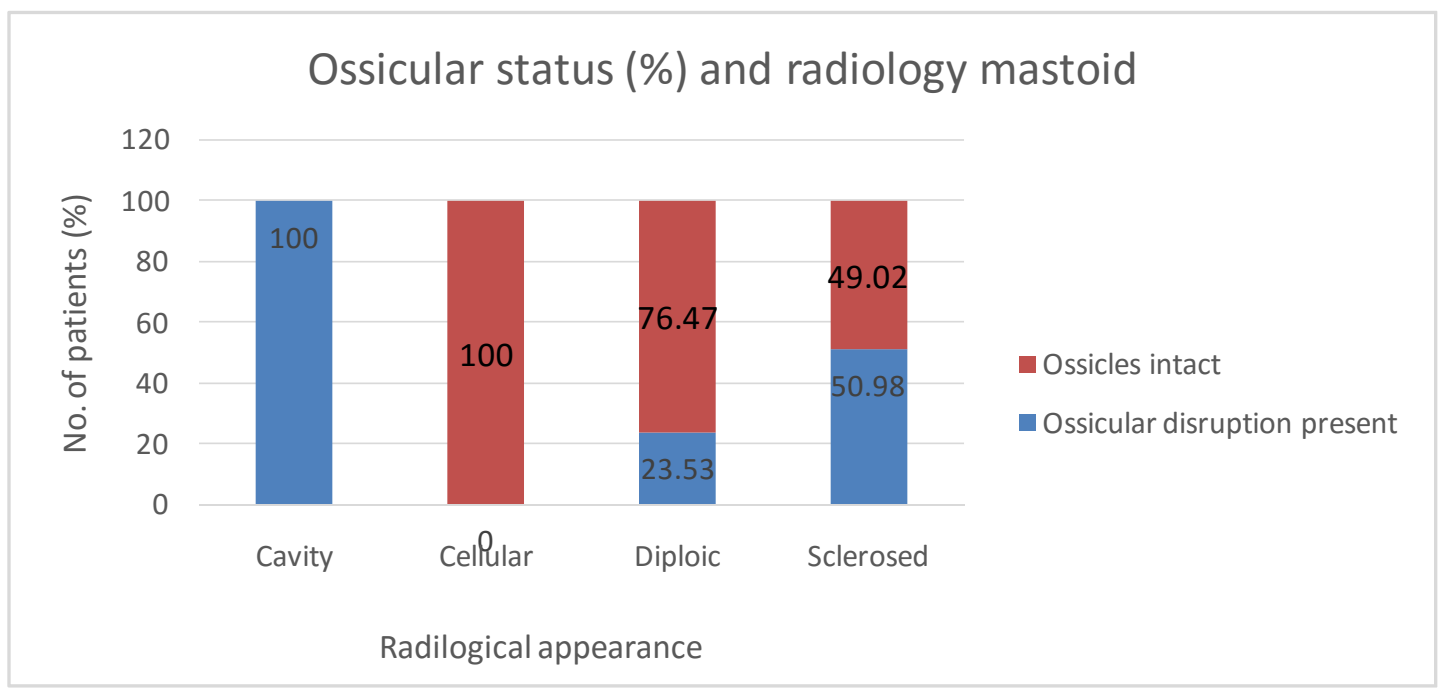

Fig 2: Ossicular status and $\mathrm{X}$-ray mastoid

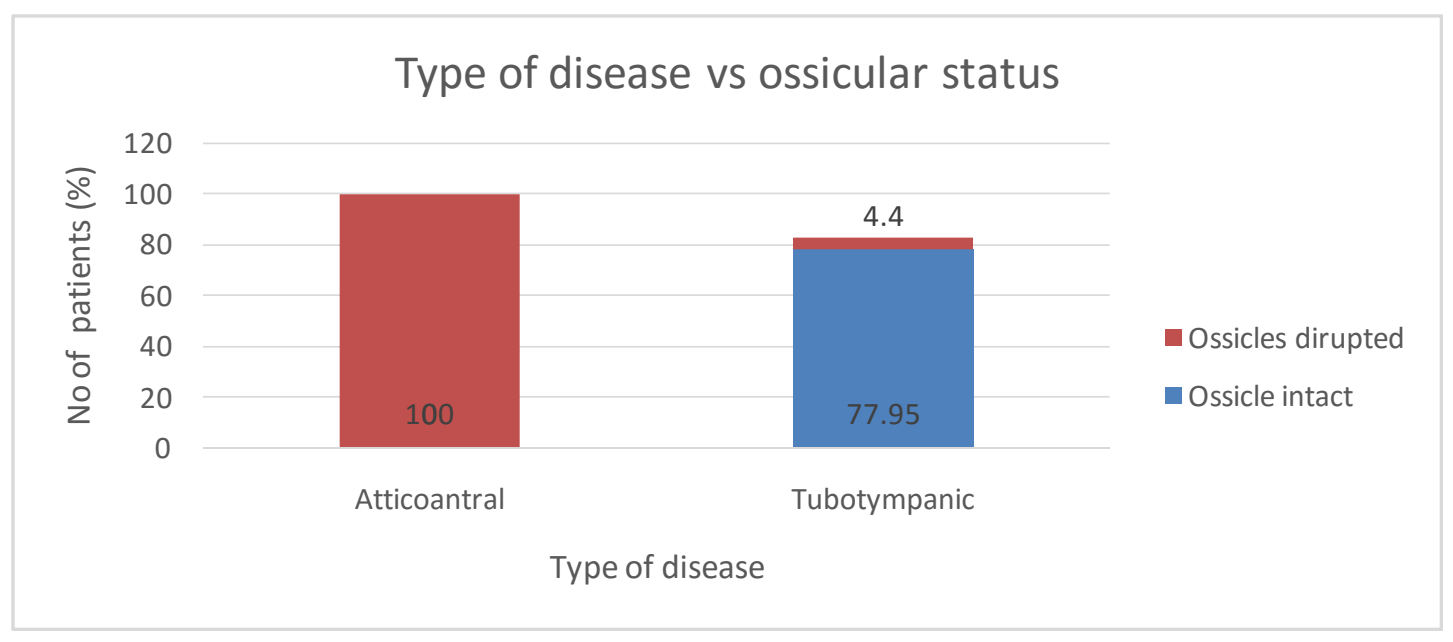

Fig-3: Type of disease vs ossicular status 


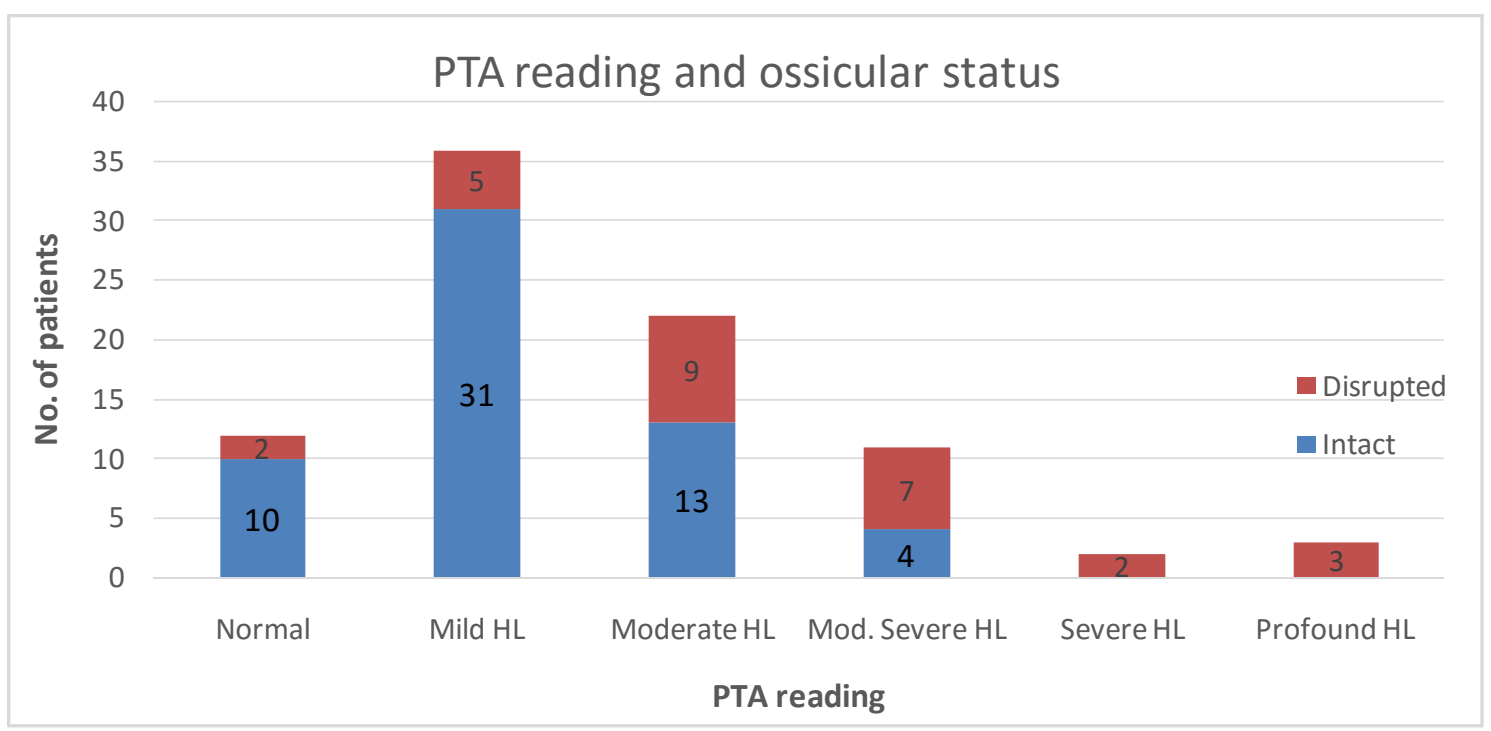

Figure-4: Ossicular status and PTA reading

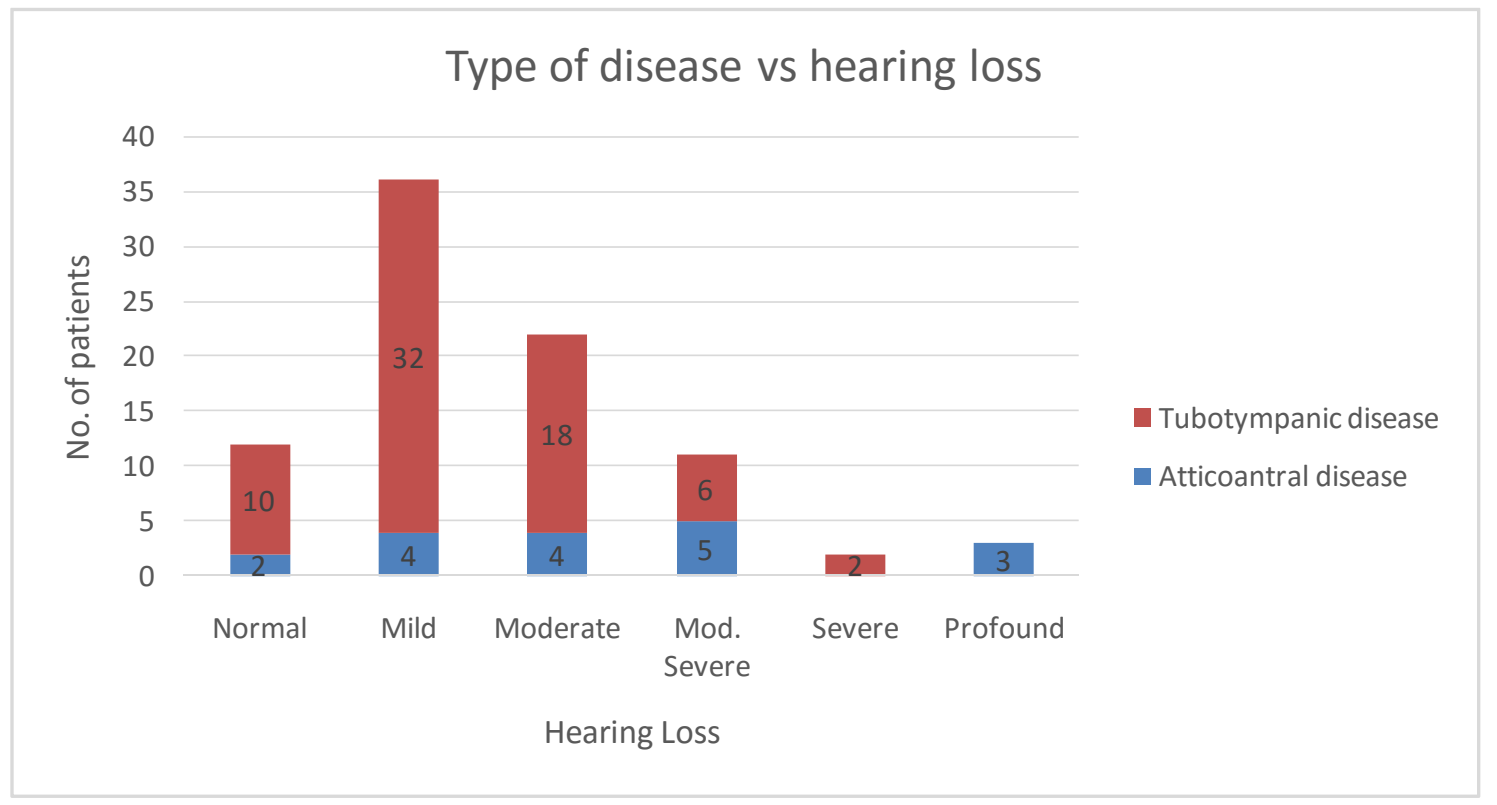

Fig-5: Type of disease vs hearing loss

Table-3: Duration of disease vs Hearing loss in Tubotympanic disease.

\begin{tabular}{|c|c|c|c|c|c|c|}
\hline \multirow{2}{*}{ Hearing loss } & \multicolumn{6}{|c|}{ Duration of disease (years) } \\
\cline { 2 - 7 } & $<\mathbf{5}$ & $\mathbf{6 - 1 0}$ & $\mathbf{1 1 - 1 5}$ & $\mathbf{1 6 - 2 0}$ & $\mathbf{2 1 - 2 5}$ & $\mathbf{2 6}$ \\
\hline Normal & 5 & 2 & 1 & 1 & - & 1 \\
\hline Mild & 17 & 10 & - & 2 & - & 2 \\
\hline Moderate & 4 & 7 & 3 & 1 & - & - \\
\hline $\begin{array}{c}\text { Moderately } \\
\text { severe }\end{array}$ & 4 & 1 & 1 & - & - & - \\
\hline Severe & - & 1 & - & - & - & 1 \\
\hline Profound & - & - & - & - & - & - \\
\hline
\end{tabular}




\section{Discussion}

CSOM is one of the commonest conditions, which the otolaryngologists come across in day to day practice. Hence it is imperative that we know the exact pathology. Surgery is frequently done in these patients for eradication of the disease process. Good postoperative functional result demands proper preoperative and peroperative assessment of the pathology, as well as their correlation with the extent of damage to the ossicular chain and hearing loss.

Eighty six patients were included in the study. Maximum numbers of patients were from the third decade of life. Children less than 10 years of age were not included in the study. Dawes (1972) suggested that children less than 10 years of age should not be operated upon as the success rate improves with age. Moreover, majority of failure in children is associated with secretory otitis media and recurrent episodes of upper respiratory tract infection [2]. Khan I et al in their study of 150 patients concluded that $45 \%$ were males and 55\% females [3]. In our study, there was a slight male preponderance $(51.16 \%)$

In our study, the incidence of tubotympanic disease was $79 \%$. It is comparable to other studies. In a study of 1717 patients by Basak et al, the incidence of tubotympanic disease was $86 \%$ [4].

The most common perforation encountered was central type with an incidence of $69.77 \%$. Kamal et al found an incidence of central perforation in CSOM of $93 \%$ in their study population of 203 [5].

The most frequently encountered pathological osseous changes in CSOM are bone resorption, fibrous thickening of mucoperiosteum, osteitis and granulation tissue and tympanosclerosis. In this study, ossicular necrosis was present in $35 \%$ of the population. However it was present in all cases of atticoantral disease. Only $15(22.05 \%)$ patients with tubotympanic disease had ossicular pathology.

The most common ossicles involved was the whole of incus (63.3\%), followed by lenticular process (53.3\%) and long process of incus (50\%). Whers R E has stated that there are four major ossicular defects that may result from erosion by cholesteatoma. The most common is involvement of incus, followed by erosion of stapes suprastructure, handle of malleus in decreasing frequency and finally there may be loss of all ossicles except stapedial footplate [6].

Grippaudo $\mathrm{M}$ in a postmortem study found that bone disease was encountered in $92 \%$ of ossicles examined. While the malleus and incus were involved with similar frequency, the extent and distribution of disease appeared greater in the incus [7].

Khan I et al in their study of 150 cases found lenticular erosion in 53 cases, malleus handle erosion and flattening in 26 cases and stapes suprastructure loss in 15 cases [3].

This study also corrected the ossicular pathology with radiological changes of the mastoid. This showed that all patients with cavity in X-ray had ossicular disruption. This was statistically significant $(\mathrm{p}<0.05)$.

Cellular mastoids failed to show any ossicular discontinuity. Sato $\mathrm{T}$ et al found that the size of pnematization in the ear with cholesteatoma was the smallest among the studied ear; they stated that pathological process influences the development of mastoid pneumatization and hypocellularity is a sequel [8].

In this study, the most common type of hearing loss encountered was mild followed by moderate. When incus was necrosed, hearing loss was mainly moderate type and with stapes necrosis, profound or moderately severe type.

Snow D.G et al found that with erosion of long process of incus the preoperative hearing was in the range of $38-40 \mathrm{~dB}$ [9]. Raine $\mathrm{C}$ H et al in a study of 14 children found that ossiculoplasty was required in nine cases because of erosion of long process on incus.

Preoperative hearing was $30 \mathrm{~dB}$ in $61 \%, 40 \mathrm{~dB}$ in $19 \%$, $41-50 \mathrm{~dB}$ in $10 \%$ and below $51 \mathrm{~dB}$ in $10 \%$. It was in this latter group that ossicular discontinuity was found during surgery [10]. Linstrom C J in his study of 24 patients found that the incus was eroded in all subjects who underwent ossiculoplasty [11].

In this study, the most common type of hearing loss in tubotympanic was mild, whereas in atticoantral disease, it was moderately severe type. 
In a comparison of duration of disease and hearing loss in patients with tubotympanic disease, the average hearing loss in those patients with disease duration less than 10 years was $39.01 \mathrm{~dB}$ whereas in patients with disease duration more than 10 years the average hearing loss was $46 \mathrm{~dB}$.

In patients suffering from atticoantral disease, the average hearing loss was independent of the disease duration. Yousry El Sayed in his study concluded that significant relationship existed between pure tone threshold elevation and disease type duration [12]. English $\mathrm{G} M$ et al found bone conduction losses increasing in severity with increasing duration of the disease and in those with more marked middle ear disease [13].

Cusimano et al in their study of 595 patients suffering from chronic otitis media, concluded that the duration of the disease does exert a significant influence on the sensorineural component in hearing loss [14]. Papp et al in a retrospective study of 121 patients with unilateral chronic suppurative otitis media, found that when age and normal side were corrected for, pure-tone threshold and bone conduction at either speech frequencies or at 4 $\mathrm{kHz}$ increased gradually according to duration of the disease [15].

\section{Conclusion}

The following conclusions were drawn from this twoyear study on ossicular pathology in chronic suppurative otits media.

Tubotympanic disease was more common than atticoantral type in the study population. Ossicular necrosis is more common in atticoantral disease. Commonest ossicle involved is incus followed by malleus. Ossicular necrosis was maximum when X-ray showed cavity in the mastoid. None of the patients with a cellular mastoid had ossicular disruption.

There was a higher incidence of ossicular disruption in atticoantral disease than in tubotympanic type. When incus or malleus necrosis was present, the hearing loss was moderate type and with stapes necrosis, it was mainly moderately severe or profound deafness.

In tubotympanic disease, the most common type of hearing loss was mild whereas in atticoantral type, hearing loss was mainly moderately severe type. In tubotympanic disease, degree of hearing loss increased with disease duration, whereas in atticoantral disease hearing loss was independent of disease duration.

It is recommended that the otologist dealing with patients suffering from chronic suppurative otitis media is familiar with the anticipated intraoperative pathology, based on clinical presentation and audiological studies. This will help the surgeon optimally plan operative procedure and give a realistic outcome of the procedure to the patient preoperatively.

Funding: Nil, Conflict of interest: None initiated, Permission from IRB: Yes

\section{References}

1. Acuin J. Chronic suppurative otitis media - Burden of illness and management options. Geneva: World Health Organization; 2004: 13-4.

2. Dawes JD. Myringoplasty. J Laryngol Otol. 1972 Feb; 86(2):141-6.

3. Khan I, Jan AM, Shahzad F. Middle-ear reconstruction : a review of 150 cases. J Laryngol Otol. 2002 Jun;1 16(6):435-9.

4. Basak B, Gayen GC, Das M, Dhar G, Ray R, Das AK. Demographic profile of CSOM in a rural tertiary care hospital. IOSR J Pharm. 2014 Jun; 4(6): 43-6.

5. Kamal N, Joarder AH, Chowdhury AA, Khan AW. Prevalence of chronic suppurative otitis media among the children living in two selected slums of Dhaka City. Bangladesh Med Res Counc Bull. 2004 Dec;30(3): 95-104.

6. Wehrs RE. Ossicular reconstruction in ears with cholesteatoma. Otolaryngol Clin North Am. 1989 Oct; 22(5):1003-13.

7. GRIPPAUDO M. Histopathological studies of the ossicles in chronic otitis media. J Laryngol Otol. 1958 Mar;72(3):177-89.

8. Sato K, Kawana M, Yamamoto Y, Fujioka O, Nakano Y. Evaluation of mastoid air cell system by three-dimensinal reconstruction using sagittal tomography of the temporal bone. Auris Nasus Larynx. 1997; 24(1): 47-51.

9. Snow DG, Robinson JM, Peters J. Bone pate repair of the eroded incus--five years on. J Laryngol Otol. 1995 Nov;109(11):1048-50. 
10. Raine CH, Singh SD. Tympanoplasty in children. A review of 114 cases. J Laryngol Otol. 1983 Mar; 97 (3):217-21.

11. Linstrom CJ, Silverman CA, Rosen A, Meiteles LZ. Bone conduction impairment in chronic ear disease. Ann Otol Rhinol Laryngol.2001 May;110(5 Pt 1):437-41.

12. El-Sayed Y. Bone conduction impairment in uncomplicated chronic suppurative otitis media. Am J Otolaryngol. 1998 May-Jun;19(3):149-53.
13. English GM, Northern JL, Fria TJ. Chronic otitis media as a cause of sensorineural hearing loss. Arch Otolaryngol. 1973 Jul;98(1):18-22.

14. Cusimano F, Cocita VC, D'Amico A. Sensorineural hearing loss in chronic otitis media. J Laryngol Otol. 1989 Feb;103(2):158-63.

15. Papp Z, Rezes S, Jókay I, Sziklai I. Sensorineural hearing loss in chronic otitis media. Otol Neurotol. 2003 Mar;24(2):141-4.

\section{How to cite this article?}

Sharma M, Shetty D.P. Ossicular status in patients operated for chronic suppurative otitis media.Int J Med Res Rev 2016;4(9):1610-1616.doi:10.17511/ijmrr. 2016.i09.16. 